\title{
Topographic Map Analysis of the North Platte River-South Platte River Drainage Divide Area, Western Larimer County, Colorado, USA
}

\author{
Eric Clausen \\ Correspondence: Eric Clausen, 100 West Ave D-17, Jenkintown, PA. E-mail: eric2clausen@gmail.com \\ Received: February 1, 2021 \\ Accepted: February 23, 2021 \\ Online Published: February 24, 2021 \\ doi:10.5539/esr.v10n1p49 \\ URL: https://doi.org/10.5539/esr.v10n1p49
}

\begin{abstract}
The United States Supreme Court settled legal disputes concerning four different Larimer County (Colorado) locations where water is moved by gravity across the high elevation North Platte-South Platte River drainage divide, which begins as a triple drainage divide with the Colorado River at Thunder Mountain (on the east-west continental divide and near Colorado River headwaters) and proceeds in roughly a north and northeast direction across deep mountain passes and other low points (divide crossings) first as the Michigan River (in the North Platte watershed)-Cache la Poudre River (in the South Platte watershed) drainage divide and then as the Laramie River (in the North Platte watershed)-Cache la Poudre River drainage divide. The mountain passes and nearby valley and drainage route orientations and other unusual erosional features can be explained if enormous and prolonged volumes of south-oriented water moved along today's north-oriented North Platte and Laramie River alignments into what must have been a rising mountain region to reach south-oriented Colorado River headwaters. Mountain uplift in time forced a flow reversal in the Laramie River valley while flow continued in a south direction along the North Platte River alignment only to be forced to flow around the Medicine Bow Mountains south end and then to flow northward in the Laramie River valley and later to be captured by headward erosion of the east-oriented Cache la Poudre River-Joe Wright Creek valley (aided by a steeper gradient and less resistant bedrock). Continued uplift next reversed flow on the North Platte River alignment to create drainage routes seen today. While explaining Larimer County North Platte-South Platte drainage divide area topographic map drainage system and erosional landform evidence this interpretation requires a completely different Cenozoic history than the geologic history geologists usually describe.
\end{abstract}

Keywords: Cache la Poudre River, diverging and converging channels, Laramie River, Michigan River, mountain passes, steam capture

\section{Introduction}

\subsection{Statement of the Problem}

The United States Supreme Court settled two legal disputes over the movement of water by gravity across the Larimer County (Colorado) North Platte-South Platte River drainage divide, yet the published geomorphology literature does not explain how that hard fought-over drainage divide came to be. How does a drainage divide between two divergent tributaries to what is now a major river originate? The North and South Platte Rivers today originate on either side of the south- and southwest-oriented Colorado River headwaters (flowing to the Pacific Ocean) and flow along completely different and divergent routes before eventually joining in western Nebraska to form the east-oriented Platte River (which joins the Missouri River with its water eventually reaching the Gulf of Mexico). Today the North Platte River originates in north central Colorado (see figure 1) as a north-northwest oriented river and after crossing the state line flows northward into central Wyoming where it makes a turn to flow in an east and then southeast direction to western Nebraska and to join the South Platte River. Most South Platte River headwaters and tributaries flow from the Colorado Front Range in southeast and east directions before joining the north-northeast oriented South Platte River, which flows through mountain canyons and then onto the plains before turning in an east and finally in a northeast direction to enter western Nebraska where it joins the southeast-oriented North Platte River.

The western Larimer County North Platte-South Platte River drainage divide origin has never been satisfactorily explained. In fact, geomorphologists have failed to explain how most United States drainage divides originated including the North American east-west continental divide. The United States Geological Survey (USGS) has published detailed topographic maps on which all evidence needed to interpret drainage divide origins is shown, yet when topographic map interpretation techniques are used drainage divide origins obtained are not consistent with accepted regional geologic histories. Those regional geologic histories were developed by following accepted Cenozoic history paradigm rules and 
assumptions, which raises the question, is the problem with the topographic maps, the topographic map interpretation techniques, or the Cenozoic history paradigm? The topographic maps represent a huge collection of mostly yet to be interpreted drainage system evidence and were prepared according to extremely high standards so the problem is probably not with the maps. Topographic map interpretation techniques are based on basic geologic principles such as the principle of cross cutting relationships and are unlikely to be causing the problem. If the maps and the map interpretation techniques are not causing the problem then the problem must be arising from a Cenozoic history paradigm flaw. This paper will determine whether topographic map interpretation techniques, without the constraint of accepted Cenozoic history paradigm rules and assumptions, can determine an internally consistent North Platte-South Platte River headwaters drainage divide origin and whether that origin is consistent with what similar topographic map interpretation techniques have determined for other regional drainage divides.

\subsection{Geographic Setting}

Larimer County is located in northcentral Colorado just south of the Wyoming state line with Jackson County located immediately to the west. The Larimer-Jackson County line follows the Medicine Bow Mountains crest (see figures 1 and 2) from the state line southward to Cameron Pass and then southward along the Never Summer Range crest. To the west in Jackson County is North Park, a mountain enclosed structural basin where the north-oriented North Platte River begins. The west -and northwest-oriented Michigan River originates just south of Cameron Pass, which in figure 2 is between the Michigan River ( $M$ on figure 2) and Joe Wright Creek ( $\mathrm{J}$ on figure 2) headwaters. The Michigan River flows to the North Platte River, which then flows in a north direction to central Wyoming where the North Platte River turns in an east and then southeast direction to join the South Platte River with their water eventually reaching the Gulf of Mexico. Immediately south of Cameron Pass and the Michigan River headwaters are south-oriented Colorado River headwaters (with water flowing to the Pacific Ocean) while north of Chambers Lake (1 on figure 2) are north-oriented Laramie River headwaters. The Laramie River flows into the Laramie Basin and where the river turns in an east and northeast direction to cross the Laramie Range (see figure 1) before joining the North Platte River.

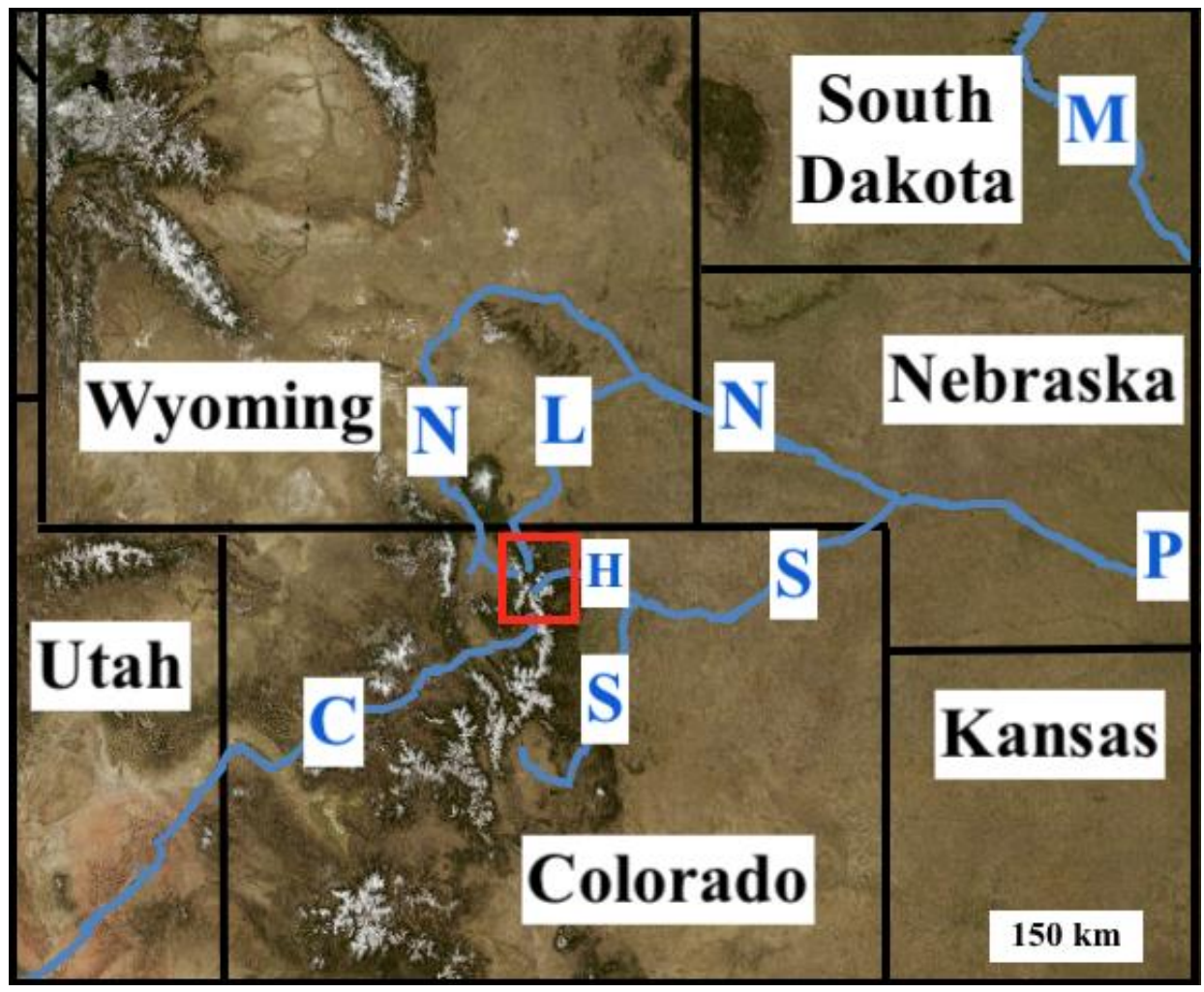

Figure 1. Modified imagery from the United States Geologic Survey (USGS) National Map website showing study region location relative to major rivers. Letters identify rivers: Colorado River (C), Cache la Poudre River (H), Laramie River (L), Missouri River (M), North Platte River (N), Platte River (P), and South Platte River (S)

Joe Wright Creek flows in a north-northeast direction from Cameron Pass to Chambers Lake and then joins the north- and east-oriented Cache la Poudre River, which is one of many east-oriented streams flowing from the high Colorado mountains to the north-northeast, east, and northeast oriented South Platte River. The Laramie Mountains are located north of the east-oriented Cache la Poudre River with the Mummy Range in the Colorado Front Range located 
immediately to the south. Today, a three-way drainage divide is located at Thunder Mountain, where the North Platte-South Platte drainage divide's southwest end meets the Colorado River drainage basin. For a short distance the North Platte-South Platte drainage divide is between the Cache la Poudre River and the Michigan River drainage basins, but for most of its distance in Larimer County the drainage divide is between the Cache la Poudre River and the Laramie River drainage basins. Also, for a distance the North Platte River-South Platte River drainage divide follows high mountain ridges including the crest of the southern Medicine Bow Mountains, before turning in an eastward direction to cross the north-oriented Laramie River valley head at Chambers Lake and then proceeding in a north-northeast direction across less well-defined uplands in the southern Laramie Mountains.

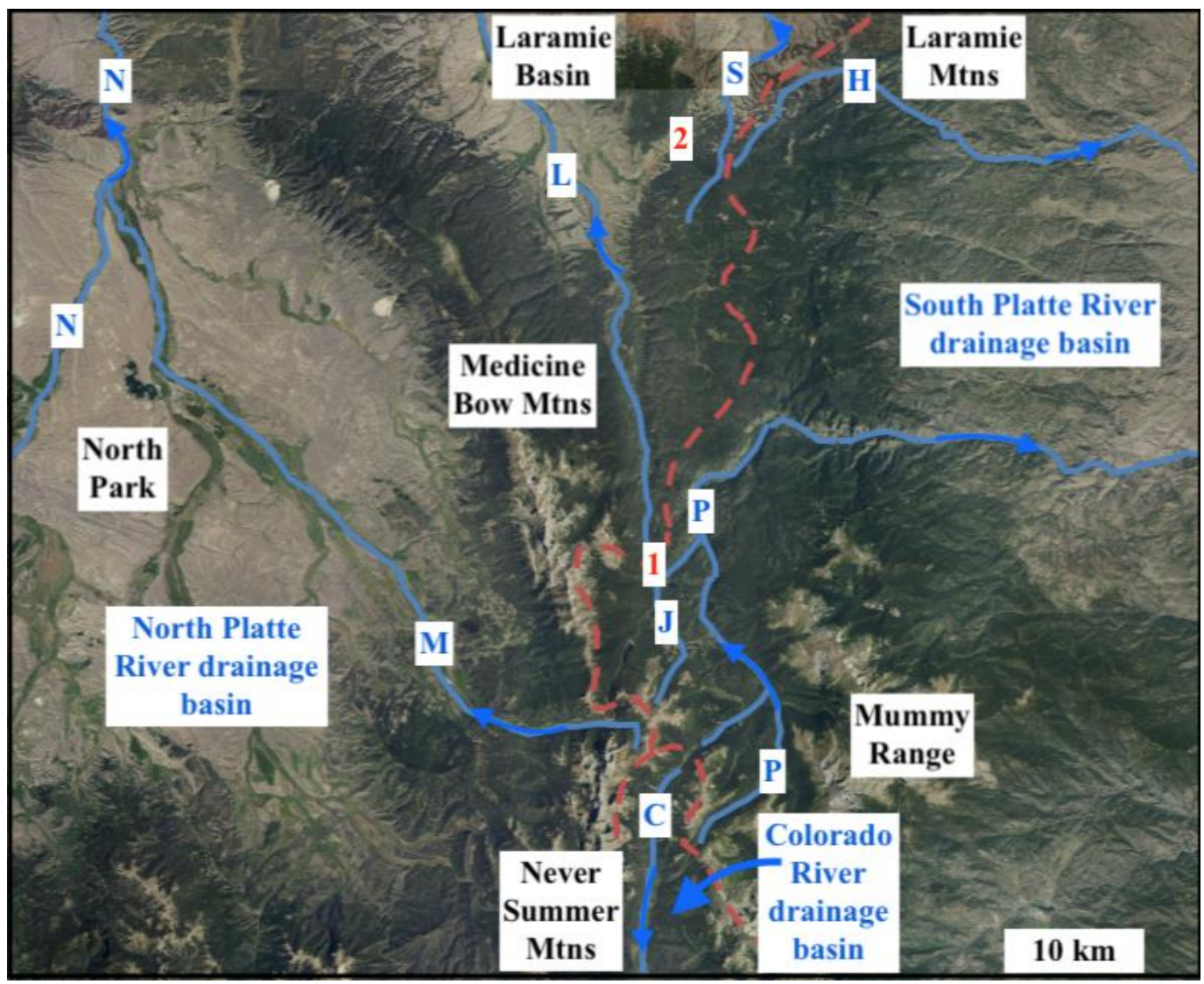

Figure 2. Modified imagery from USGS National Map website showing study area drainage divides (red dashed lines) and drainage routes (blue lines with arrows showing flow directions). Letters identify drainage routes as follows:

Colorado River (C), Sheep Creek (H), Joe Wright Creek (J), Michigan River (M), North Platte River (N), and Cache la

Poudre River (P). The red number 1 locates Chambers Lake and the red number 2 locates Sand Creek Pass

\subsection{Previous Work}

Detailed topographic maps available at the USGS National Map website represent this paper's most significant previous work. The maps show drainage routes, drainage divides, through valleys (or divide crossings including mountain passes), drainage orientations, barbed tributaries, and other features required to determine a region's drainage history. Most information, while available on topographic maps since the mid $20^{\text {th }}$ century, has not been used to reconstruct western Larimer County geomorphic history. For example, Harris (1963) in a paper titled "Geomorphology of Larimer County, Colorado" does not mention topographic map interpretation nor does he discuss the North Platte-South Platte drainage divide or the mountain passes and unusual features such as abrupt drainage direction changes and numerous barbed tributaries. Topographic map interpretation is rarely mentioned in more recent regional geologic history papers including an Anderson et al paper (2006) with a title starting with the words "Facing Reality" in which aerial photos and digital elevation models are discussed, but in which topographic map interpretation is not mentioned.

The first workers to recognize unusual Larimer County (Colorado) North and South Platte River drainage divide features were not geomorphologists, but irrigators seeking additional water sources. Laflin (2005, p.26-27) describes how in the 1880s irrigators determined Cameron Pass could be used to move water from the Michigan River drainage basin (in the North Platte watershed) to the Cache la Poudre River drainage basin (in the South Platte watershed) and soon water was diverted from the Michigan River watershed to Joe Wright Creek. In 1891 water began moving on an 8-kilometer-long 
ditch from the West Branch Laramie River to Chambers Lake (in the Cache la Poudre watershed). In 1897 a local rancher conceived the idea of a 3.5-km tunnel across a narrow North Platte-South Platte drainage divide segment that when completed in 1911 diverted Laramie River water to the Cache la Poudre River. An additional 1.5-kilometer-long irrigation ditch moves water from Sand Creek in the Laramie River drainage basin to Sheep Creek in the Cache la Poudre drainage basin. These water diversions across the North Platte-South Platte drainage divide led to a series of court battles which the United States Supreme Court settled in 1922 and 1932 (in cases titled State of Wyoming vs. State of Colorado).

While courts discussed water movements across the North Platte-South Platte drainage divide geomorphologists focused their attention on high-level erosion surfaces. William Morris Davis (1911) first described what he named the "Highland peneplain of the Front Range." Researchers soon saw more erosion surfaces with Lee (1922) and others describing two such surfaces while Van Tuyl and Lovering (1935) argued for five erosion surfaces. Not only did workers see different numbers of erosion surfaces, but workers could not agree on the erosion surface ages. For example, Mears (1993, p. 609) observes, "A late Eocene age for the prominent sub-summit surface is the doctrine for most geologists in Colorado. However, dissenters in Wyoming consider the surface late Miocene." As a Colorado geologist Bolyard (1997, p. 125) suggested "the Mummy Range and Medicine Bow Mountains rose about 3000 feet (914 meters) above a Late Eocene erosion surface which had developed by stream erosion on Precambrian crystalline rock [and that] ...Volcanic rocks were extruded on this surface during Oligocene and Miocene time [and that] ...Mio-Pliocene uplift was accompanied by canyon-cutting [and] stream piracy caused a major change in the course of the Cache la Poudre River." He suggests the Miocene Cache la Poudre River flowed northeastward (in a region east of this paper's study area) and weaker bedrock and a steeper gradient probably contributed to its capture.

USGS and other geologists have also produced geologic maps covering all Larimer County North Platte-South Platte drainage divide areas. The Workman et al (2018) map and associated text covers all Larimer County and adjacent Jackson County and Wyoming areas pertinent to this paper. Other pertinent geologic maps include the Braddock and Cole (1978) preliminary geologic map of the Greeley Quadrangle, the Braddock and Cole (1990) geologic map of Rocky Mountain National Park, the Kellogg et al (2010) geologic map of the Clark Peak Quadrangle, and the Workman and Braddock (2010) geologic map of the Sand Creek Pass Quadrangle. In addition to the USGS geologic maps other geologists have published reports describing the region's structural geology which include the Beckwith (1942) paper on the structure of the Upper Laramie River Valley and work by Blackstone (1996) in a report on the structural geology of the Laramie Mountains. More recently Wohl (2008) published a report describing bedrock jointing in Cache la Poudre drainage basin areas downstream from this paper's study region.

Using topographic map evidence and topographic map interpretation techniques Clausen (2020a) suggested high mountain passes now crossing the east-west continental divide between the North and South Platte River headwaters and the Colorado River headwaters had been eroded by diverging and converging flood flow channels moving water southward from what is now the north-oriented North Platte River drainage basin to what are now southeast- and east-oriented South Platte River headwaters while the south-oriented Colorado River valley eroded headward into a rising mountain region. This interpretation requires a different Cenozoic history than is accepted, however it explains topographic map evidence not only in the Colorado River headwaters area, but also along the North Platte River drainage route. For example, headward erosion of the southeast-oriented North Platte River valley along the Laramie Range northeast flank is described by Clausen (2019) as beheading and reversing multiple south-oriented flood flow channels. Along the southcentral Wyoming Great Divide Basin eastern margin Clausen (2020b) describes evidence for south-oriented drainage on what is now the north-oriented North Platte River alignment. Turning to the Laramie River drainage basin Clausen (2018) describes an anastomosing canyon complex crossing the Laramie Mountains and leading to the Goshen Hole basin. Further, Clausen (2020c) describes how a large east-oriented flood-formed anastomosing channel complex heading along the Laramie Mountains crest ridge was systematically captured by headward erosion of south-oriented valleys from an actively eroding northeast-oriented South Platte River valley and by headward erosion of a north-oriented valley from an actively eroding southeast-oriented North Platte River valley. These Clausen papers all used detailed topographic maps and topographic map interpretation techniques to describe drainage divide origins, but describe a different Cenozoic geologic history than the accepted paradigm describes.

\section{Research Method}

More than 40 years ago the author of this paper, Clausen, began using detailed topographic maps to determine where continental ice sheet meltwater had once flowed. At first those efforts were unsuccessful because accepted regional glacial histories do not satisfactorily explain the detailed topographic map evidence. Finally, in 1999 a decision was made to do what became a three-year a systematic study of drainage divide evidence found on the thousands of detailed topographic maps covering the entire Missouri River drainage basin. The goal of that intensive study was to determine how drainage divides within and surrounding the Missouri River drainage basin originated. Results suggested the need for a new regional Cenozoic history paradigm defined by a rule requiring most Missouri River drainage basin valleys large enough 
to be shown on the detailed maps to have eroded headward across large south- and southeast-oriented floods. That rule forces recognition of a large North American continental ice sheet (in the recognized North American continental ice sheet location), which deeply eroded underlying bedrock (deep continental ice sheet erosion is not usually recognized in many glaciated areas) and which weighed enough to raise adjacent mountain ranges and continental areas as massive south-oriented meltwater floods flowed across the rising regions (accepted geologic histories do not usually link regional and mountain uplift to continental ice sheets). The initial 1999-2001 study was done using hard copy topographic maps and the study was repeated beginning in 2011 and ending in 2013 using National Geographic TOPO maps and software.

This investigation used detailed topographic maps available at the USGS National Map website and the cited geologic maps to follow the North Platte-South Platte River drainage divide across Larimer County. Low points located along the drainage divide were interpreted to be evidence water had once flowed across the drainage divide. Also noted were unusual nearby erosional landform and drainage features, such as abrupt drainage direction changes, barbed tributaries, water-eroded diverging and converging channels, and bedrock unit ages that might help date when deep erosion began. Water was assumed to have eroded all existing stream and river valleys (including through valleys and mountain passes), although subsequent alpine glaciation was recognized to have probably deepened and otherwise altered the higher elevation valleys. Observed evidence was treated as a solvable puzzle in which it was necessary to move water across what was probably a rising mountain region in a way that would result in the present-day set of valleys, abandoned valleys (including through valleys and mountain passes), and drainage divides. Water movements and mountain and regional uplifts as suggested in Clausen (2020a) were tested and found consistent with observed map evidence. Those water movement and regional and mountain uplift interpretations were further tested for consistency with water movements and uplifts suggested in other cited and uncited Clausen papers.

\section{Results}

\subsection{Thunder Mountain to Diamond Peaks}

Figure 3 illustrates the North Platte-South Platte drainage divide segment between Thunder Mountain and Diamond Peaks. The North Platte-South Platte drainage divide begins at Thunder Mountain (letter "T" and elevation 3727 meters) where a triple drainage divide marks the boundary between the North Platte drainage basin in Jackson County (west), South Platte drainage basin in Larimer County (east), and Colorado River drainage basin in Grand County (south). North of Thunder Mountain is Iron Mountain (letters IM and 3738 meters) and an unnamed (on the map) pass (number 1 and elevation 3437 meters) between the two peaks links the west-oriented Michigan River (M, which flows to the North Platte) with southeast-oriented Neota Creek (letter N), which flows to northeast-oriented La Poudre Creek (letters LP). La Poudre Creek flows to the Cache la Poudre River (a South Platte River tributary). Neota Creek joins La Poudre Creek as a barbed tributary almost at La Poudre Pass (number 4 and 3104 meters), which links the Cache la Poudre River drainage basin with Colorado River (letter C) headwaters. The Braddock and Cole (1990) geologic map shows Thunder Mountain and Iron Mountain higher elevations covered by upper Oligocene rhyolite and and welded tuff and the unnamed 300-meter-deep pass floor covered by Holocene and Quaternary colluvium.

From Iron Mountain (IM) the North Platte-South Platte drainage divide follows high mountain ridges in a northwest and west direction before crossing Cameron Pass (number 2 and elevation 3132 meters), which links a south-oriented Michigan River tributary valley with north-northeast oriented Joe Wright Creek (J), which flows to Chambers Lake and then to the Cache la Poudre River. Prior to reaching the final high point just before descending into Cameron Pass the North Platte-South Platte drainage divide is located on upper Oligocene trachyandesite and basalt before reaching what the Kellogg et al (2010) map shows as early Proterozoic granite gneiss, which continues into Cameron Pass and which is also found near the top of Diamond Peaks along with early Proterozoic biotite-muscovite schist and gneiss. Cameron Pass and lower slopes around it are shown to be covered by late Pleistocene glacial tills. After crossing Cameron Pass the drainage divide ascends the pass valley wall to Diamond Peaks ( $\mathrm{D}$ with the highest point at 3612 meters). Faulting along what is mapped as a concealed thrust fault extending through Cameron Pass explains rock type differences on either side of the pass. However, Cameron Pass is also a 500- to 600-meter-deep erosional landform and had to be eroded by large volumes of water that flowed across what is now the North Platte-South Platte drainage divide.

To better understand the drainage divide history, we need to look at a short stretch of the North Platte-Colorado River drainage divide. Immediately to the southwest of Thunder Mountain (T) is Lulu Mountain (elevation 3727 meters) and then Thunder Pass (elevation 3454 meters) with the drainage divide then rising in a south direction to cross more high peaks. The Michigan River originates near Thunder Pass and flows in a north direction before turning in a west direction so as to create an enclosed Michigan River headwaters basin, which today drains in a west direction, but which has three significant abandoned outlets or inlets (Cameron Pass, the unnamed pass at number 1, and Thunder Pass). Today an irrigation ditch begins just south of the letter $\mathrm{M}$ and diverts water from north-oriented Michigan River tributaries and headwaters (in the North Platte River drainage basin) in a large semi-circle along the enclosed Michigan River headwaters 
basin wall to cross Cameron Pass and to reach Joe Wright Creek (in the South Platte River drainage basin). While the region was subsequently glaciated water almost certainly eroded the valleys and abandoned valleys (including the mountain passes).

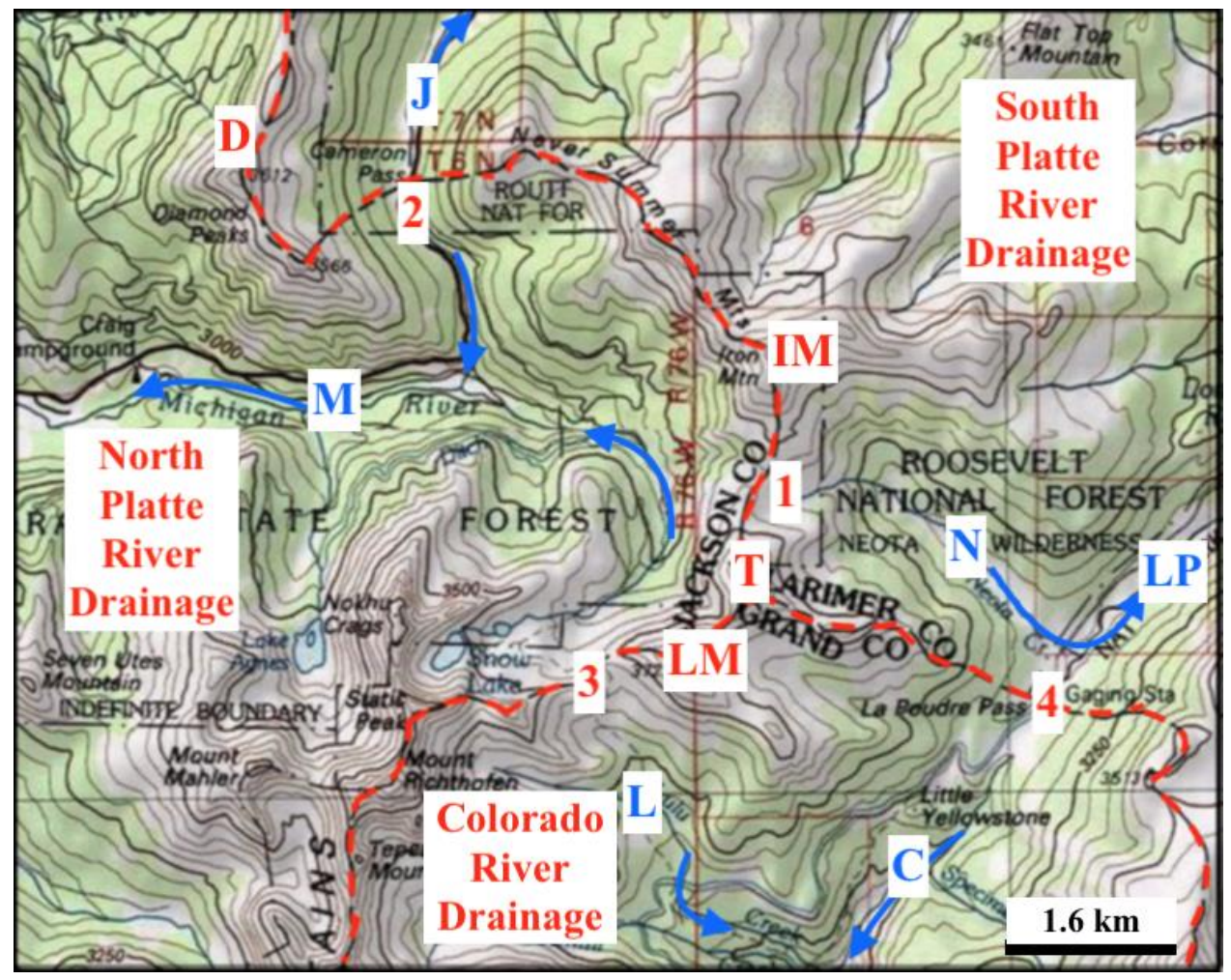

Figure 3. Modified USGS topographic map showing southwest end of North Platte-South Platte drainage divide. Numbers and letters identify an unnamed pass (1), Cameron Pass (2), Thunder Pass (3), La Poudre Pass (4), Colorado River (C), Diamond Peaks (D), Iron Mountain (IM), Joe Wright Creek (J), Lulu Creek (L), Lulu Mountain (LM), La Poudre Creek (LP in the unlabeled South Platte drainage basin), Michigan River (M), Neota Creek(N) and Thunder Mountain (T)

Assuming alpine glaciation did not significantly deepen the mountain passes the problem is to figure out how running water eroded the four mountain passes to produce present-day drainage divides and drainage routes. If water eroded all valleys, we need to start by looking at the two passes with the highest floor elevations. Those two passes are the unnamed pass between Thunder Mountain and Iron Mountain and Thunder Pass, which have remarkably similar floor elevations and which link the Platte River drainage basin with the Colorado River drainage basin. The similar pass floor elevations suggest the two passes were eroded at the same time and the question can be asked, were the two passes eroded by water flowing northward from the Colorado drainage basin to the Platte drainage basin or was the water flowing southward from the Platte drainage basin to the Colorado drainage basin? Note how Neota Creek flows to La Poudre Creek as a barbed tributary, which suggests it originally flowed across La Poudre Pass into the Colorado River headwaters valley. If so, the two high elevation mountain passes suggest diverging streams of water flowed southward from the Michigan River drainage basin around what are now Thunder and LuLu Mountains and converged in the Colorado River valley.

If water flowed through the two high elevation mountain passes from the Platte drainage basin to the Colorado River, the Michigan River valley and the Cameron Pass floors at that time must have been at least as high as the two mountain pass floors, which are now approximately 300 meters higher than the Cameron Pass floor (if the Cameron Pass floor and/or Michigan River valley floor had been lower, no water could have flowed from the Michigan River headwaters basin to the Colorado River.) The next question is how did enough water get into the Michigan River headwaters basin so as carve two 300-meter deep diverging channels into resistant bedrock (i.e. upper Oligocene igneous rock)? One possibility is large volumes of water flowed in a south direction from the now north-oriented Laramie River drainage basin and then across Cameron Pass, another possibility is large volumes of water flowed in a south direction along the now north-oriented North Platte River drainage route and then in a southeast and east direction along the Michigan River alignment, and a third possibility is large and prolonged volumes of water initially flowed in a south direction on the now north-oriented North Platte River and Laramie River alignments, but flow on the Laramie River alignment was reversed while south-oriented flow continued on the North Platte River alignment. However, each possibility requires major mountain 
uplift since upper Oligocene time to create drainage routes seen today.

Today the North Platte River flows in a north direction into central Wyoming (see figure 1) where it turns to flow in an east and then southeast direction into western Nebraska. The Laramie River joins the southeast-oriented North Platte River in western Nebraska and it is difficult to imagine large volumes of south-oriented water in the Laramie River while water in the North Platte River headwaters area was flowing in a north direction, so the first possibility needs to be rejected. It is possible large volumes of water flowed in a south direction on what are now the north-oriented Laramie and North Platte River alignments and as mountain uplift occurred Laramie River flow was reversed (to flow in a north direction to reach the downstream southeast-oriented North Platte River) while south-oriented flow continued on the now north-oriented North Platte River alignment. Cameron Pass is approximately 300 meters deeper than Thunder Pass and the unnamed pass between Thunder Mountain and Iron Mountain, which suggests south-oriented water on the North Platte River alignment would have made a U-turn in what is now the Michigan River headwaters basin to then flow through Cameron Pass so as to reach the then north-oriented Joe Wright Creek and Laramie River valleys. Continued regional uplift would have eventually reversed flow on what is now the north-oriented North Platte River alignment, which would have ended flow across Cameron Pass and created the west and northwest-oriented Michigan River drainage route.

\subsection{Diamond Peaks to Chambers Lake}

From an elevation of 3612 meters at Diamond Peaks the North Platte-South Platte drainage divide continues in a north direction along the southern Medicine Bow Mountains crest to Montgomery Pass. Montgomery Pass (elevation about 3355 meters and about 100 meters lower than previously mentioned passes crossing the continental divide, but 223 meters higher than Cameron Pass) links the west- and northwest-oriented North Fork Michigan River with east- and northeast-oriented tributaries to north-northeast oriented Joe Wright Creek and is the low point on a 3-kilometer or longer stretch of lower elevations along the Medicine Bow Range crest ridge between Diamond Peaks and Clark Peak (elevation 3947 meters). Elevations along this lower elevation crest segment are often 200 meters or more lower than crest elevations to the north and the higher Diamond Peaks area elevations to the south. The Braddock and Cole map (1990) shows crest ridge bedrock in the Montgomery Pass area as biotite schist and hornblende gneiss of early Proterozoic age with dashed fault lines running through the pass (dashed fault lines on the map indicate approximate locations). Montgomery Pass and the stretch of lower crest elevations probably record where water flowed in a south direction on the present-day north-oriented North Platte River alignment and then around the southern end of what was probably a rising Medicine Bow Range so as to flow in a north direction in the Laramie River valley and also to the what was probably an actively eroding Cache la Poudre River valley (at the same time water was making a similar U-turn and eventually eroding a deeper valley further to the south along the previously described Michigan River-Cameron Pass alignment).

After following the Medicine Bow Range crest northward from Diamond Peaks and Montgomery Pass to Clark Peak the North Platte-South Platte drainage divide leaves the crest ridge and crosses an unnamed pass (elevation about 3363 meters) near Blue Lake and then rises to the Cameron Peak top (elevation 3696 meters). The unnamed pass links northeast-oriented West Branch Laramie River with southeast- and east-oriented Fall Creek flowing to Chambers Lake (and Joe Wright Creek) and may have been eroded by south-oriented water diverging from the Laramie River alignment to flow on a route defined by the north-northeast oriented West Branch Laramie River and southeast- and east-oriented Fall Creek alignments to reach the Cache la Poudre valley. An irrigation ditch today leads from the West Branch Laramie River along the Cameron Peak eastern slope to Joe Wright Creek at Chambers Lake. From Cameron Peak the North Platte-South Platte drainage divide descends to the Chambers Lake north shore (elevation 2790 meters). Harris (1963) describes Chambers Lake as impounded behind glacial moraines. Today Chambers Lake drains to north-northeast oriented Joe Wright Creek, which flows to a north-oriented Cache la Poudre River segment (in the South Platte watershed) and it is probable that when the Blue Lake pass (between Clark and Cameron Peaks) was eroded water in the now north-oriented Cache la Poudre headwaters valley was flowing in a south direction to reach an actively eroding south-oriented Colorado River headwaters valley. Workman et al (2018, p. 5) state the Laramie River (in the North Platte watershed) begins to the north of the lake's northernmost point and "flows in a graben formed in a structural syncline." Bolyard (1997, p. 131) notes an "obvious north-south lineament approximately 40 miles (54 km) long is formed by the upper reaches of the Colorado and Laramie Rivers".

\subsection{Chambers Lake to Green Ridge Area}

The distance from Chambers Lake at the Laramie River headwaters valley head to the north-oriented Cache la Poudre River valley is about three kilometers and abandoned valleys now cross the North Platte-South Platte drainage divide. The North Platte-South Platte drainage divide continues northward on the narrow upland between the north-oriented Laramie River to the west and north-oriented Joe Wright Creek and Cache la Poudre River to the east until the Tunnel Creek through valley is reached. Tunnel Creek drains that east-oriented valley to the Cache la Poudre River valley, which turns in an east and then northeast direction (see figure 4). The Laramie River at the west end of that through valley is roughly 
160 meters higher than the Cache la Poudre River and the 3-km long Laramie-Poudre Tunnel extends under the through valley (which at the drainage divide is almost 300 meters higher than the Laramie River) and diverts Laramie River water to the Cache la Poudre River. Northward from the Laramie-Poudre Tunnel the North Platte-South Platte drainage divide follows Green Ridge, the crest of which is approximately equidistant from the north-oriented Laramie River and the northeast-oriented Cache la Poudre valley until the drainage divide crosses a shallow upland valley between Nunn Creek (west) and south- and southeast-oriented Roaring Creek (east).

Roaring Creek is one of several south-oriented tributaries flowing to the Cache la Poudre River near where the Cache la Poudre River turns abruptly from flowing in a northeast direction to flow in a southeast and then east direction. The Cache la Poudre River direction change suggests a capture took place with headward erosion of a deep southeast- and east-oriented Cache la Poudre River valley capturing north- and northeast-oriented Cache la Poudre River drainage. However south-oriented tributaries flowing to the Cache la Poudre River suggest headward erosion of the Cache la Poudre River valley also captured multiple south-oriented drainage routes. How can this conflicting evidence be reconciled? Clausen (2020a) suggests south-oriented flood flow moving in the now north-oriented Cache la Poudre River headwaters valley flowed to and across La Poudre Pass to erode the Colorado River headwaters valley, but mountain uplift forced a flow reversal to create the north-oriented Cache la Poudre River headwaters seen today. South-oriented water diverging from the Laramie River (before flow was reversed) probably carved the Tunnel Creek through valley as the water moved in a south direction on what is now the north-oriented Cache la Poudre River headwaters alignment. Other through valleys radiate from the Chambers Lake area to the north-oriented Cache la Poudre River headwaters valley and suggest multiple channels moving south-oriented water once diverged from the now north-oriented Laramie River valley head. South-oriented flood flow in the Laramie River valley would also have once moved to the Colorado River headwaters along the Cameron Pass route, but mountain uplift blocked that route at an earlier time.

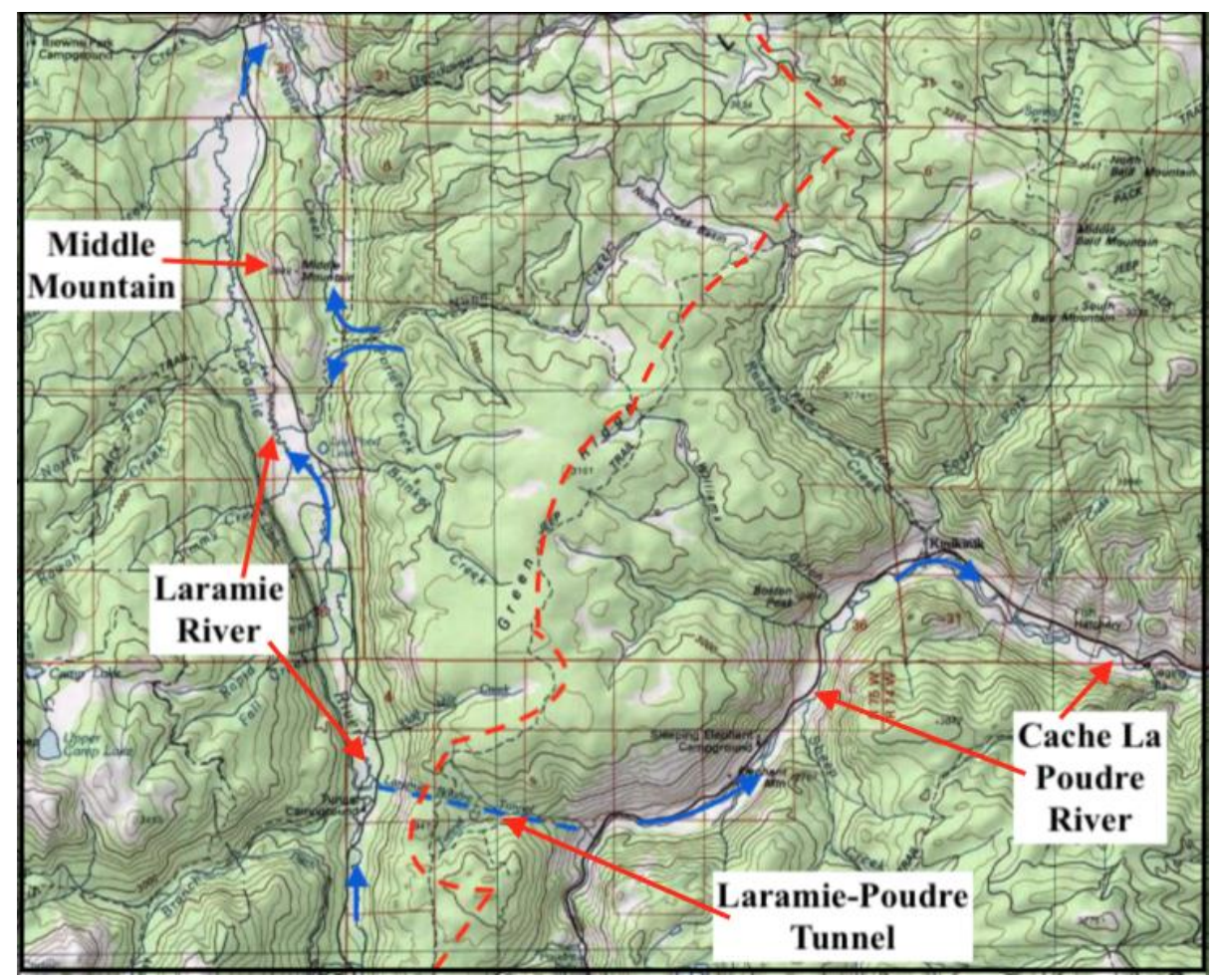

Figure 4. Modified USGS topographic map showing Laramie-Cache la Poudre River drainage divide (red dashed line) and the Laramie-Poudre Tunnel and Middle Mountain locations north of Chambers Lake. Grid square side lengths are about 1.6 kilometers. Contour interval is 50 meters

West of where the North Platte-South Platte drainage divide crosses between the Nunn Creek and Roaring Creek Beckwith (1942, p. 1496) described two longitudinal valleys and an intervening ridge named Middle Mountain, which "is a rounded ridge that terminates in a sharp peak of pre-Cambrian rocks at 9300 feet" [ 2848 meters and 320 meters higher than the west valley floor and 220 meters higher than the eastern valley floor]. Today the north-oriented Laramie River flows in the western valley and Nunn Creek flows in a west direction into the eastern valley and then turns in a north direction to flow on the eastern valley floor to the Laramie River while Porter Creek flows in a north and then west direction to almost join Nunn Creek on the eastern valley floor, but instead turns to flow in a south direction on the valley floor and joins the Laramie River as a barbed tributary. Middle Mountain (as observed on topographic maps) reminded 
this paper's author (Clausen) of Steamboat Rock, which stands above the Upper Grand Coulee floor (in Washington State) and which according to Bretz (1928, p. 461) is an erosional remnant left after massive floods eroded deep channels on either side. Map evidence suggests massive flooding also carved Middle Mountain, perhaps first by south-oriented floodwaters moving to the Colorado River and later by north-oriented floodwaters.

\subsection{Sand Creek Pass Area}

One of the most intriguing North Platte-South Platte drainage divide segments is illustrated in figure 5 and is located along the Laramie Basin southern margin (just south of the Wyoming state line). The Laramie River flows in a northwest direction to the west of figure 5 at the foot of Bull Mountain (partially seen in the figure northwest quadrant) and Sand Creek flows in a north direction from highlands in the figure south center area and descends in the figure northeast quadrant (and eventually joins the north-oriented Laramie River). Note how Sand Creek for a short distance is almost flowing along the North Platte-South Platte drainage divide and how Sheep Creek originates along that drainage divide segment and then flows in northeast and east directions (to the east of figure 5 Sheep Creek water eventually reaches the Cache la Poudre River). Today a short drainage ditch (starting at an elevation of about 2739 meters) leads from Sand Creek to Sheep Creek and carries water across the drainage divide. West of that ditch is Sand Creek Pass, where the drainage divide elevation between southwest- and northwest-oriented Jimmy Creek and north-oriented Sand Creek is 2736 meters. The similarity of the two elevations is remarkable and a closer look is needed.

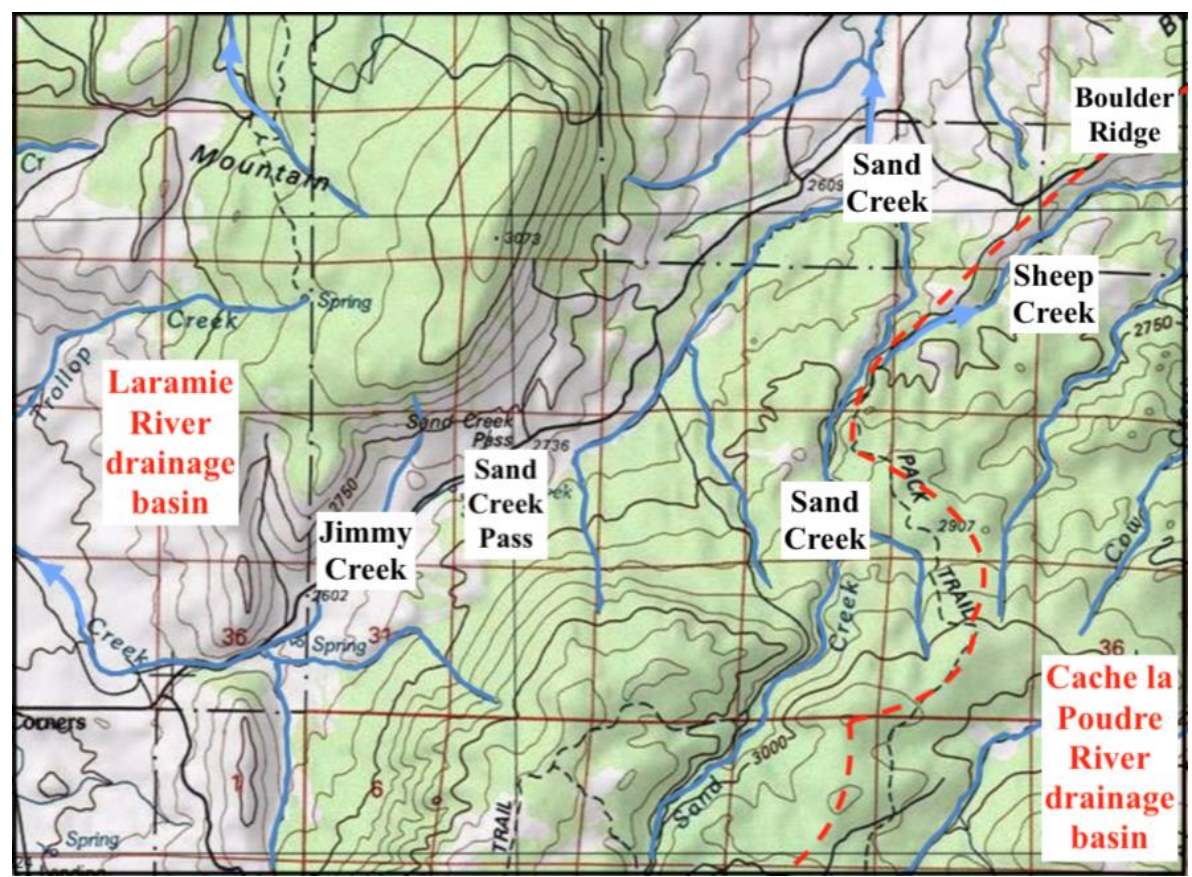

Figure 5. Modified USGS topographic map of Sand Creek Pass-Bull Mountain area (just south of the Wyoming state line).

Dashed red line shows North Platte-South Platte drainage divide. Sides of squares in grid are $1.6 \mathrm{~km}$ in length. The contour interval is 50 meters

Workman et al (2018, p. 5) state Bull Mountain to the northwest of Sand Creek Pass "consists of folded Phanerozoic strata along the southern margin of the Laramie Basin," but do not address further the Sand Creek Pass origin. Workman and Braddock (2010) mapped the high western Bull Mountain ridge to the north of Sand Creek Pass as Lower Cretaceous Dakota Group sandstone interbedded with shale and siltstone and with a chert-pebble conglomerate at the base. Their map shows Jurassic and Triassic units exposed along the steep east-facing slope and Permian dolomites, shales, siltstones, and sandstones exposed along the Sand Creek Pass valley floor. Bull Mountain is mapped as a synclinal structure and the Sand Creek Pass valley is a structurally controlled valley, although it is also a water-eroded feature. Harris (1963) considers the high point (elevation 3073 meters) on the ridge north of Sand Creek Pass to be a Summit Peneplain remnant (or a remnant of the Rocky Mountain high-level erosion surface). In any case water erosion carved the 330-meter-deep valley between that high Bull Mountain ridge and the Laramie Mountains and that water, whichever direction it flowed came from the Laramie River valley and then reentered the Laramie River valley.

Bull Mountain and an area to the west and northwest appear to be a large erosional remnant (like the previously discussed Middle Mountain erosional remnant) left as large volumes of water carved deep diverging and converging valleys into a rising mountain area. Only partially seen in figure 5 are abandoned valleys linking northeast-oriented Sand Creek tributaries with southwest-oriented tributaries flowing to the northwest-oriented Laramie River. Those abandoned valleys 
include Horse Ranch Pass (elevation about 2619 meters) and Red Mountain Pass (elevation about 2512 meters) and are water eroded valleys. The Sand Creek Pass valley and abandoned valleys suggest a large diverging and converging channel complex developed where large north-oriented Laramie River flows emerged into the Laramie Basin from the structurally confined valley further to the south. The Sand Creek-Sheep Creek irrigation ditch suggests Sheep Creek valley headward erosion from the Cache la Poudre valley almost captured north-oriented Sand Creek and north-oriented flows were of sufficient magnitude and duration to erode the Sand Creek Pass through valley. These features are difficult to explain unless massive and prolonged floods flowed around the Medicine Bow Mountains southern margin and then in a north direction into the Laramie Basin as Clausen (2018, 2020a, and 2020c) suggested.

\section{Discussion and Conclusions}

Topographic map interpretation techniques suggest the entire Colorado and Wyoming region and mountains were being uplifted as large and prolonged south-oriented floods moved along the now north-oriented Laramie and North Platte River alignments to reach an actively eroding south-oriented Colorado River headwaters valley. Colorado and Wyoming regional and mountain uplift eventually blocked south-oriented flood flow routes to the Colorado River valley and forced a flow reversal in the Laramie River valley while south-oriented floodwaters continued to flow on the North Platte River alignment with the water then flowing in a southeast and east direction along the Michigan River headwaters alignment before turning to flow northward through (and further deepen) Cameron Pass and then further north along the Laramie River alignment to reach the Laramie Basin. Once in the Laramie Basin (in Wyoming north of this paper's study region) the floodwaters crossed the rising Laramie Mountains to reach the southeast-oriented North Platte River valley (see Clausen, 2018). At the same time Cache la Poudre River valley headward erosion (from the actively eroding South Platte River valley) began to capture floodwaters making the large U-turn (in the Chambers Lake and Sand Pass regions). Headward erosion of the southeast-oriented North Platte River valley into central Wyoming combined with regional and mountain uplift eventually beheaded and reversed south-oriented flow on the north-oriented North Platte River alignment to create drainage routes and drainage divides seen today (see Clausen 2019).

While the above-described water movements and tectonic and erosion events explain the detailed topographic map drainage system and erosional landforms discussed here and are consistent with water movements and topographic map drainage system and erosional landform evidence described in the cited Clausen papers (2018, 2019, 2020a, 2020b, and 2020c) a major problem exists. Immense and prolonged volumes of water are required and while large North American continental ice sheets might generate huge and long-lived south-oriented meltwater floods the accepted Cenozoic history paradigm considers the high Colorado and Wyoming plateaus and mountains and many of their drainage features to have existed before any large North American continental ice sheets developed. In other words, the map evidence described here is from the accepted Cenozoic history paradigm perspective what Thomas Kuhn (1970) refers to as anomalous or unexplainable evidence. Paradigms according to Kuhn are judged based on their ability to explain evidence and large quantities of anomalous evidence can lead to new paradigms. This paper along with the cited (and other uncited) Clausen papers are using vast quantities of yet to be explained North and South Platte River drainage basin and other topographic map drainage system and erosional landform evidence to describe a fundamentally different and new Cenozoic history paradigm in which a large North American continental ice sheet caused crustal warping as immense south-oriented meltwater floods flowed across and eroded what must have been rising Wyoming and Colorado regions and mountains. Paradigms are difficult to change, but the vast quantities of unexplained topographic map drainage system and erosional landform evidence suggest a future Cenozoic geologic history paradigm change is inevitable.

\section{Acknowledgements}

Arthur Strahler introduced numerous unsolved drainage history problems while the author was a student at Columbia University and shortly thereafter Brainerd Mears, Jr, then at the University of Wyoming introduced additional unsolved Rocky Mountain area drainage history problems, including the Sand Creek Pass problem discussed here. Research that led to this paper was done while employed as a faculty member at Minot State University where other faculty members, students, and library staff members helped in accessing hard copy topographic maps.

\section{Conflict of interests}

The author declares that there is no conflict of interests regarding the publication of this paper.

\section{References}

Anderson, R. S., Riihimaki, C. A., Safran, E. B., \& MacGregor, K. R. (2006). Facing reality: Late Cenozoic evolution of smooth peaks, glacially ornamented valleys, and deep river gorges of Colorado's Front Range. Geological Society of America Special Paper, 398, 397-418. https://doi.org/10.1130/2006.2398(25)

Beckwith, R. H. (1942). Structure of the upper Laramie River Valley, Colorado-Wyoming. Bulletin of the Geological Society of America, 53(10), 1491-1532. https://doi.org/10.1130/GSAB-53-1491 
Blackstone, D. L. (1996). Structural geology of the Laramie Mountains, southeastern Wyoming and northeastern Colorado (Doctoral dissertation, University of Wyoming. Libraries).

Bolyard, D. W. (1997). Late Cenozoic history of the Northern Colorado Front Range. In Bolyard, D. W. and Sonnenberg, S. A. eds. (1997) Geologic History of the Colorado Front Range. Rocky Mountain Association of Geologists, 125-134.

Braddock, W. A., \& Cole, J. C. (1978). Preliminary geologic map of the Greeley 1 degree by 2 degrees Quadrangle, Colorado and Wyoming (No. 78-532). https://doi.org/10.3133/ofr78532

Braddock, W. A., \& Cole, J. C. (1990). Geologic map of Rocky Mountain National Park and vicinity, Colorado (No. 1973).

Bretz, J. H. (1928). The channeled scabland of eastern Washington. Geographical Review, 18(3), 446-477. https://doi.org/10.2307/208027

Clausen, E. (2018). Topographic Map Analysis of Laramie Range Bedrock-Walled Canyon Complex and the Goshen Hole Escarpment-Surrounded Basin, Albany and Platte Counties, Southeast Wyoming, USA. Open Journal of Geology, 8(1), 33-55. https://doi.org/10.4236/ojg.2018.81003

Clausen, E. (2019). Use of Stream and Dismembered Stream Valleys Now Crossing Wyoming's Northern Laramie Mountains to Test a Recently Proposed Regional Geomorphology Paradigm, USA. Open Journal of Geology, 9(11), 731-751. https://doi.org/10.4236/ojg.2019.911087

Clausen, E. (2020a). Topographic map analysis of mountain passes crossing the Continental Divide between Colorado headwaters and North and South Platte River headwaters to test a new geomorphology paradigm, Colorado, USA. Journal of Geography and Geology, 12(1), 50-64. https://doi.org/10.5539/jgg.v12n1p50

Clausen, E. (2020b). Use of topographic map evidence from drainage divides surrounding Wyoming's Great Divide Basin to compare two fundamentally different regional geomorphology paradigms. Earth Science Research, 9(1), 45-57. https://doi.org/10.5539/esr.v9n1p45

Clausen, E. (2020c). Use of topographic map evidence of the southeast Wyoming Gangplank area to compare two fundamentally different geomorphology paradigms, USA. Open Journal of Geology, 10, 261-279. https://doi.org/10.4236/ojg.2020.104014

Davis, W. M. (1911). The Colorado Front Range. Association of American Geographers Annals, 1, 21-84. https://doi.org/10.2307/2560844

Harris, D. (1963). Geomorphology of Larimer County, Colorado. In Bolyard, D. W. and Katich, P. J. eds. (1963) Geology of the Northern Denver Basin and Adjacent Uplifts: Fourteenth Field Conference, Colorado, Wyoming, Nebraska, and South Dakota. Rocky Mountain Association of Geologists, 196-204.

Kellogg, K. S., Ruleman, C. A., Shroba, R. R., \& Braddock, W. A. (2010). Geologic map of the Clark Peak Quadrangle, Jackson and Larimer Counties, Colorado. United States Geologic Survey, Scientific Investigations Map SIM-3010, scale 1:24,000. https://doi.org/10.3133/sim3010

Kuhn, T. (1970). The structure of scientific revolutions: second edition, enlarged. University of Chicago Press, Chicago. 210p.

Laflin, R. (2005). Irrigation, Settlement, and change on the Cache la Poudre River. Colorado Water Resources Research Institute Special Report Number 15, Colorado State University, 174p.

Lee, W. T. (1922). Peneplains of the Front Range at Rocky Mountain Park: US Geol. Survey Bull, (730-A), 1-17.

Mears Jr, B. (1993). Geomorphic history of Wyoming and high-level erosion surfaces. Geology of Wyoming: Laramie, Geological Survey of Wyoming Memoir, 5, 608-626.

Supreme Court of the United States (1922). State of Wyoming v. State of Colorado. 259 U.S. 419.

Supreme Court of the United States (1932). State of Wyoming v. State of Colorado. 286 U.S. 494.

Van Tuyl, F. M., \& Lovering, T. S. (1935). Physiographic development of the Front Range. Bulletin of the Geological Society of America, 46(9), 1291-1350. https://doi.org/10.1130/GSAB-46-1291

Wohl, E. (2008). The effect of bedrock jointing on the formation of straths in the Cache la Poudre River drainage, Colorado Front Range. Journal of Geophysical Research: Earth Surface, 113(F1). https://doi.org/10.1029/2007JF000817

Workman, J. B., \& Braddock, W. A. (2010). Geologic Map of the Sand Creek Pass quadrangle, Larimer County, 
Colorado and Albany County, Wyoming. United States Geological Survey Scientific Investigations Map 3133 , scale 1:24,000. https://doi.org/10.3133/sim3133

Workman, J. B., Cole, J. C., Shoba, R. R., Kellogg, K. S., \& Premo, W. R. (2018). Geologic map of the Fort Collins 30'x60' quadrangle, Larimer and Jackson Counties, Colorado, and Albany and Laramie Counties, Wyoming. United States Geologic Survey Scientific Investigations Map 3399 and pamphlet 83 p. scale 1:100,000. https://doi.org/10.3133/sim3399

\section{Copyrights}

Copyright for this article is retained by the author(s), with first publication rights granted to the journal.

This is an open-access article distributed under the terms and conditions of the Creative Commons Attribution license (http://creativecommons.org/licenses/by/4.0/). 